УДК 658.155:[637.5:005.936.3](477.74)

DOI: 10.15673/fie.v10i2.965

Маркова Т.Д.

кандидат економічних наук, старший викладач E-mail: markova.tetiana17@gmail.com
Тройніна В.В.

магістрант

E-mail:verba1409@yahoo.com

\author{
Чорна С.В. \\ магістрант \\ кафедра обліку та аудиту \\ Одеська національна академія харчових технологій \\ вул. Канатна, 112, м. Одеса, Україна, 65039 \\ E-mail: sv.chornaya@yandex.ru
}

\title{
ОЦІНКА ВПЛИВУ ВИТРАТ І ДОХОДІВ НА ФІНАНСОВІ РЕЗУЛЬТАТИ НА ПРИКЛАДІ ПП ФІРМА «ГАРМАШ»
}

\begin{abstract}
У статті розглядається сутність поняття «витрати», «собівартість», «доходи», «фрінансовий результат», теоретичні та практичні аспекти організації обліку витрат і доходів діяльності та фрінансових результатів на підприємстві. Враховуючи складний фінансовий стан у всіх галузях економіки і значна кількість збиткових підприємств і організацій, досліджено динаміку і структуру витрат на прикладі ПП Фірми «Гармаш». Враховуючи значну частину операційних витрат, проведено їх аналіз за економічними витратами, аналіз впливу окремих факторів на зміну собівартості реалізованої продукції, аналіз витрат на 1 гривню продукції. Визначено основні групи факторів, що впливають на фінансові результати підприємства.

Пропонується в умовах сучасної адаптації для успішної організації обліку і оцінки наявності та зміни фінансового результату підвищити рівень застосування облікових даних для оцінювання, контролю та запобігання перевитрат. Виявлено, що одним із шляхів ефективної конкурентоздатності в сучасних умовах ведення бізнесу є своєчасне виявлення причин перевитрат і прийняття рішень, щодо їх усунення.
\end{abstract}

Ключові слова: фрінансові результати, витрати на 1 грн, витрати діяльності, собівартість, доходи діяльності, прибуток, збиток.

This work is licensed under a Creative Commons Attribution 4.0 International License http://creativecommons.org/licenses/by/4.0/

Постановка проблеми та її зв'язок 3 важливими науковими та практичними завданнями. Для будь-якого підприємства, одним з суттєвих показників ефективності фінансового-господарської діяльності $є$ позитивний фінансовий результат, а саме прибуток. Фінансовим результатом підприємства може бути прибуток, збиток або нульовий результат, тобто прибуток дорівнює витратам. Слід відмітити, що прибуток $\epsilon$ першочерговою основою фінансування діяльності підприємства. Адже, саме від величини цього показника залежить рівень погашення кредиторської заборгованості підприємства та можливості його перспективного економічного розвитку. Проблематика питання «доходи діяльності», «витрати діяльності» та «фінансові результати» обговорюються як у науковій сфері, так і на практиці в процесі управління фінансово-господарською діяльністю. Ці категорії, на нашу думку мають як різні відмінності, так й особливий взаємозв'язок. Про актуальність обраного нами питання засвідчує складне фінансове становище у всіх сферах економіки і чимала кількість збиткових підприємств і організацій України.

Аналіз останніх публікацій 3 проблеми. Актуальні питання організації ефективного обліку доходів і витрат діяльності та забезпечення отримання позитивного фінансового результату найбільш широко висвітлено в працях таких вітчизняних вчених, як І.А. Бєлоусової, М.Т. Білухи, Ф.Ф. Бутинця, С.Ф. Голова, В.В. Сопка, Н.В. Чебанової, Т.І. Сфіменко, Г.Г. Кірейцева, І.А. Ламикіна, В.Г. Лінника, Ю.Я. Литвина, Т. Маренич, В.Б. Моссаковського, Л.В. Нападовської, М.Ф. Огійчука, В.Ф. Палія, Л.І. Хорунжого, М.Г. Чумаченко, Н.М. Ткаченко та багато інших. Але, ряд важливих питань щодо оцінки та впливу доходів та витрат на фінансовий результат в умовах сучасної адаптивності залишаються не висвітлені та потребують як теоретичної, так і практичної уваги та підтверджують актуальність даного дослідження.

Формулювання цілей дослідження. Мета роботи - розкриття сутності «доходи», «витрати», «фінансовий результат», оцінка впливу доходів та витрат діяльності на фінансові результати у сучасних умовах ринку - окреслила низку завдань:

- визначення сутності «доходи», «витрати», «собівартість», «фінансовий результат»;

- аналіз динаміки і структури витрат ПП Фірми «Гармаш»; 
- аналіз операційних витрат за економічними витратами ПП Фірми «Гармаш»;

- аналіз витрат на 1 гривню реалізованої продукції ПП Фірми «Гармаш»;

- аналіз впливу окремих факторів на зміну собівартості реалізованої продукції ПП Фірми «Гармаш»;

- обгрунтування факторів, що впливають на фінансовий стан підприємства.

Виклад основних результатів та їх обгрунтування. Поняття «фінансовий результат» трактується різними авторами по-різному [1]. Але найбільш частіше зустрічається як доходи діяльності підприємства за вирахуванням витрат діяльності. Слід підкреслити, що велика кількість дефініцій терміна «фінансовий результат» викликана як існуванням різних підходів до розуміння досліджуваного поняття (економічний, фінансовий, обліковий тощо), так й тим, що кожен з науковців розглядає фінансові результати або в певній галузі економіки, або прив'язуючи їх до конкретного завдання чи об'єкта бухгалтерського обліку.

Облік доходів і витрат діяльності підприємства $\epsilon$ однією з вагомих ділянок обліково-аналітичної роботи бухгалтера. Своєчасно та прозоро необхідно формувати інформацію щодо доходів і витрат підприємства (організації) за їх видами, передбачати нарахування і перерахування податків, які поповнюють державний бюджет України.

Діяльність підприємств направлена на отримання прибутку та його раціонального розподілу та використання, а за наявності збитків - на виявлення їх причин та джерел відшкодування. Слід відзначити, що доходи підприємства бувають від різних сфер діяльності, тобто від операційної діяльності, інвестиційної, фінансової, тощо.

Слід відмітити, що сутність поняття «доходи», «витрати» розкривається як в нормативнозаконодавчій базі, так і в науково-економічній літературі. Більше того, в нормативно-законодавчих документах, можемо зустріти майже тотожні дефініції. Так, наприклад, у П(С)БО 1 «Загальні вимоги до фінансової звітності» [2], Податковому Кодексі України [3] та П(С)БО 16 «Витрати» [4] витрати - це зменшення економічних вигод у вигляді вибуття активів або збільшення зобов'язань, внаслідок чого відбувається зменшення власного капіталу. А, доходи, навпаки, збільшення економічних вигод у вигляді надходження активів або зменшення зобов'язань, які призводять до зростання власного капіталу (за винятком зростання капіталу за рахунок внесків власників) [2].

Відзначимо, що будь-яке підприємство в процесі фінансово-господарської діяльності потребує витрати як матеріальних, так і трудових. 3 досліджуваної динаміки і структури витрат ПП Фірми «Гармаш» (табл.1) спостерігаємо, що значна частина витрат - це операційна діяльність, а саме, собівартість реалізованої продукції. Структура витрат у звітному році у порівнянні 3 попереднім змінилась за рахунок збільшення витрат на собівартість у звітному році, також зменшились фінансові витрати у звітному році.

Таблиця 1

Динаміка і структура витрат ПП Фірма «Гармаш»*

\begin{tabular}{|c|c|c|c|c|c|c|c|c|}
\hline \multirow[b]{2}{*}{ № } & \multirow[b]{2}{*}{ Показники } & \multirow{2}{*}{$\begin{array}{c}\text { Код } \\
\text { рядка } \\
\text { ф.№2 }\end{array}$} & \multicolumn{2}{|c|}{ Попередній рік. } & \multicolumn{2}{|c|}{ Звітній рік } & \multicolumn{2}{|c|}{ Відхилення } \\
\hline & & & $\begin{array}{l}\text { Сума } \\
\text { тис.грн }\end{array}$ & $\begin{array}{l}\text { Струк } \\
\text { тура\% }\end{array}$ & $\begin{array}{l}\text { Сума } \\
\text { тис.грн }\end{array}$ & $\begin{array}{l}\text { Струк } \\
\text { тура\% }\end{array}$ & $\begin{array}{l}\text { Сума } \\
\text { тис.грн }\end{array}$ & Пунктів \\
\hline & $\mathrm{A}$ & 1 & 2 & 3 & 4 & 5 & 6 & 7 \\
\hline 1. & $\begin{array}{l}\text { Собівартість реалізованої } \\
\text { продукції (товарів, робіт, } \\
\text { послуг) }\end{array}$ & 2050 & 54920 & 87,64 & 62134 & 90,95 & 7214 & 13,13 \\
\hline 2. & Адміністративні витрати & 2130 & 2895 & 4,62 & 2838 & 4,15 & -57 & $-1,97$ \\
\hline 3. & Витрати на збут & 2150 & 4237 & 6,76 & 3231 & 4,73 & -1006 & $-23,74$ \\
\hline 4. & Інші операційні витрати & 2180 & - & - & - & - & - & - \\
\hline & $\begin{array}{l}\text { Всього витрат } \\
\text { операційної діяльності } \\
(1+2+3+4)\end{array}$ & & 62052 & - & 68203 & - & 6151 & 9,91 \\
\hline \multicolumn{9}{|c|}{ Інвестиційна та фінансова діяльність } \\
\hline 5. & Фінансові витрати & 2250 & 615 & 0,98 & 113 & 0,17 & -502 & $-81,63$ \\
\hline 6. & $\begin{array}{l}\text { Втрати від участі в } \\
\text { капіталі }\end{array}$ & 2255 & - & - & - & - & - & - \\
\hline 7. & Інші витрати & 2270 & - & - & - & - & - & - \\
\hline & Всього витрат $(5+6+7)$ & & 615 & - & 113 & - & -502 & $-81,63$ \\
\hline & Разом по підприємству & & 62667 & 100,0 & 68316 & 100,0 & 5649 & $\mathrm{x}$ \\
\hline
\end{tabular}

*Розраховано авторами за даними фінансової звітності підприємства

У бухгалтерському обліку собівартість - це вартісна оцінка ресурсів, використаних у процесі до- сягнення певних цілей. Підприємство має самостійно визначати перелік витрат, які включають до собівар- 
тості продукції (робіт, послуг) як елемент облікової політики, грунтуючись на економічній сутності понесених витрат і загальних принципах бухгалтерського обліку та вимог до організації його ведення. Тлумачення сутності поняття собівартості розглядається різними вченими [5- 9], а також нормативнозаконодавчою базою. Так, згідно П(С)БО 16 «Витрати», собівартість реалізованої продукції (робіт, послуг) складається з виробничої собівартості продукції (робіт, послуг), яка була реалізована протягом звітного періоду, нерозподілених постійних загальновиробничих витрат та наднормативних виробничих витрат [4]. Таким чином, на нашу думку, собівартість - це один з основних показників підприємства, виражений в грошовій формі, який акумулює всі витрати пов'язані 3 виробництвом і реалізацією продукції. Слід відмітити, що показник собівартості дуже важливий для підприємства у плануванні прибутку, визначення економічної ефективності виробництва загалом, а також для формування сучасної ринкової ціни та підвищення конкурентоспроможність продукції як на вітчизняній, так й на міжнародній арені.

Враховуючи значну частину операційних витрат, проведено аналіз операційних витрат за економічними витратами (табл.2).

Таблиця 2

Аналіз операційних витрат за економічними витратами ПП Фірма «Гармаш»*

\begin{tabular}{|l|c|c|c|c|c|c|}
\hline \multirow{2}{*}{\multicolumn{1}{|c|}{ Показники }} & \multicolumn{2}{c|}{$\begin{array}{c}\text { Попередній } \\
\text { рік }\end{array}$} & \multicolumn{2}{c|}{ Звітний } & \multicolumn{2}{c|}{ Відхилення } \\
\cline { 2 - 8 } & тис.грн & $\%$ & тис.грн & $\%$ & абс. & $\%$ \\
\hline $\begin{array}{l}\text { 1.Матеріальні витрати (за вирахуванням вартості зворотних } \\
\text { відходів) }\end{array}$ & 44588 & 71,8 & 52617 & 77,1 & 8029 & 18 \\
\hline 2.Амортизація & 4002 & 6,5 & 2969 & 4,4 & -1033 & $-25,8$ \\
\hline 3.Витрати на оплату праці & 9591 & 15,4 & 8293 & 12,2 & -1298 & $-13,5$ \\
\hline 4.Відрахування на соціальні заходи & 3447 & 5,6 & 3023 & 4,4 & -424 & $-12,3$ \\
\hline 5.Інші операційні витрати & 424 & 0,7 & 1301 & 1,9 & 877 & 206,8 \\
\hline Всього операційних витрат & 62052 & 100 & 68203 & 100 & 6151 & 9,91 \\
\hline
\end{tabular}

*Розраховано авторами за даними фінансової звітності підприємства

За даними табл. 2 видно, що продукція підприємства $\epsilon$ досить матеріаломісткою. Матеріальні затрати у попередньому році складають 44588 тис. грн. (або 71,8\%), витрати на оплату праці складають 9591 тис. грн. (або 15,4 \%), амортизація - 4002 тис. грн. (або 6,5\%), інші операційні витрати - 424 тис грн. (або 0,7\%), та відрахування на соціальні заходи 3447 тис. грн. (або 5,6 \%). У звітному році відбулись такі зміни: матеріальні витрати зросли на 8029 тис грн. (або на 18\%), витрати на оплату праці зменшились на 1298 тис. грн. (або на 13,5\%), амортизація зменшилась на 1033 тис. грн. (або 25,8\%), відраху- вання на соціальні заходи зменшилась на 424 тис. грн. (або на 12,3\%), інші операційні витрати збільшились на 877 тис. грн., тобто удвічі більше.

Крім аналізу операційних витрат за економічними елементами, аналіз витрат операційної діяльності передбачає проведення аналізу витрат на гривню вартості реалізованої продукції. Витрати на одну гривню продукції визначаються як відношення витрат основної операційної діяльності та здійснюють за даними форми №2 «Звіт про фінансові результати» (табл. 3).

Таблиця 3

Аналіз витрат на 1 гривню реалізованої продукції ПП Фірма «Гармаш»*

\begin{tabular}{|c|c|c|c|c|}
\hline \multirow{2}{*}{ Показники } & \multirow{2}{*}{$\begin{array}{l}\text { Попередній } \\
\text { рік }\end{array}$} & \multirow{2}{*}{ Звітний рік } & \multicolumn{2}{|c|}{ Відхилення } \\
\hline & & & абс. & $\%$ \\
\hline $\begin{array}{l}\text { 1. Чистий дохід (виручка) від реалізації продукції (това- } \\
\text { рів, робіт, послуг), тис.грн }\end{array}$ & 60321 & 66149 & 5828 & 9,66 \\
\hline $\begin{array}{l}\text { 2. Собівартість реалізованої продукції (товарів, робіт, } \\
\text { послуг), тис.грн }\end{array}$ & 54920 & 62134 & 7214 & 13,14 \\
\hline 3.Адміністративні витрати, тис. грн & 2895 & 2838 & -57 & $-1,96$ \\
\hline 4.Витрати на збут, тис.грн & 4237 & 3231 & -1006 & $-23,74$ \\
\hline 5.Повна собівартість реалізованої продукції, тис.грн & 62052 & 68203 & 6151 & 9,91 \\
\hline \multicolumn{5}{|l|}{ 6. Витрати на 1 гривню продукції, коп. виходячи: } \\
\hline - із собівартості реалізованої продукції & 91,05 & 93,93 & 2,88 & 3,17 \\
\hline - із повної собівартості & 102,87 & 103,11 & 0,24 & 0,23 \\
\hline
\end{tabular}

*Розраховано авторами за даними фінансової звітності підприємства 
Наведені в табл. 3 дані показують, що у звітному році витрати на 1 грн. реалізованої продукції зросли в порівнянні з попереднім роком на 2,88коп., або на $3,17 \%$, а повної собівартості - на $0,23 \%$ і становить у звітному році 103,11 коп., що свідчить про перевищення витрат над доходами, тобто про збитки.
Оцінка цього показника за два роки свідчить про необхідність негайно виявлених причин та їх усунення. Аналіз впливу окремих факторів на економію чи перевитрати собівартості реалізованої продукції в звітному році порівняно з попереднім здійснюємо за допомогою табл. 4.

Таблиця 4

Факторний аналіз змін витрат на 1 грн. реалізованої продукції ПП Фірма «Гармаш»*

\begin{tabular}{|l|c|c|c|}
\multicolumn{1}{|c|}{ Показники } & $\begin{array}{c}\text { Попередній } \\
\text { рік }\end{array}$ & Звітний рік & $\begin{array}{c}\text { Абсолютне відхилен- } \\
\text { ня }\end{array}$ \\
\hline $\begin{array}{l}\text { 1.Витрати на 1 грн. реалізованої продукції, } \\
\text { коп., }\end{array}$ & 102,87 & 103,11 & 0,24 \\
\hline $\begin{array}{l}\text { В т.ч. } \\
\text { - по собівартості реалізованої продукції }\end{array}$ & 91,05 & 93,93 & 2,88 \\
\hline - по адміністративним витратах & 4,78 & 4,29 & $-0,49$ \\
\hline - по витратах на збут & 7,02 & 4,88 & $-2,14$ \\
\hline
\end{tabular}

*Розраховано авторами за даними фінансової звітності підприємства

Як видно з даних табл. 4 головною причиною зростання витрат на 1 грн. реалізованої продукції стало зменшення витрат на збут, яке стало 2,14 коп. та зменшення адміністративних витрат на 0,49 коп. Тому завданням аналізу витрат діяльності є виявлення причин зменшення витрат на збут з 4237 тис. грн. до 3231 тис. грн. при тому, що обсяг реалізації збільшився на 9,66\%.

Відзначмо, що зменшення витрат на 1 грив- ню реалізованої продукції приводить до загальної економії витрат на виробництво та реалізацію продукції, а зростання витрат на 1 гривню реалізованої продукції приводить до загальних перевитрат на виробництво та реалізацію продукції.

Аналіз впливу окремих факторів на економію чи перевитрати собівартості реалізованої продукції в звітному році порівняно з попереднім наведено в табл. 5.

Таблиця 5

Аналіз впливу окремих факторів на зміну собівартості реалізованої продукції ПП Фірма «Гармаш»*

\begin{tabular}{|c|c|c|c|c|c|c|}
\hline \multirow[b]{2}{*}{ Елементи витрат } & \multicolumn{2}{|c|}{ Попередній рік } & \multicolumn{2}{|c|}{ Звітний рік } & \multicolumn{2}{|c|}{ Відхилення } \\
\hline & 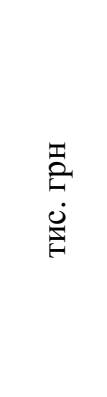 & 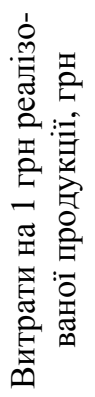 & 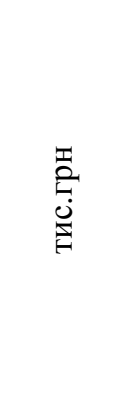 & 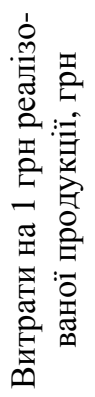 & ஜ̈ & 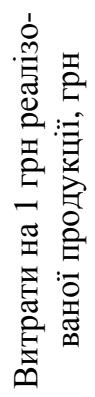 \\
\hline $\begin{array}{l}\text { 1. Чистий дохід (виручка) від реалізації про- } \\
\text { дукції (товарів, робіт, послуг), тис.грн }\end{array}$ & 60321 & $\mathrm{X}$ & 66149 & $\mathrm{X}$ & 5828 & $\mathrm{X}$ \\
\hline $\begin{array}{l}\text { 2.Матеріальні витрати (за вирахуванням вар- } \\
\text { тості зворотних відходів) }\end{array}$ & 44588 & 0,72 & 52617 & 0,77 & 8029 & 0,05 \\
\hline 3.Амортизація & 4002 & 0,06 & 2969 & 0,05 & -1033 & $-0,01$ \\
\hline 4.Витрати на оплату праці & 9591 & 0,15 & 8293 & 0,12 & -1298 & $-0,03$ \\
\hline 5.Відрахування на соціальні заходи & 3447 & 0,06 & 3023 & 0,04 & -424 & $-0,02$ \\
\hline 6.Інші операційні витрати & 424 & 0,01 & 1301 & 0,02 & 877 & 0,01 \\
\hline Всього операційних витрат & 62052 & 1,00 & 68203 & 1,00 & 6151 & - \\
\hline
\end{tabular}

*Розраховано авторами за даними фінансової звітності підприємства

Дані таблиці показують збільшення операційних витрат на 877тис. грн., або на 0,01\% матеріальні витрати (за вирахуванням вартості зворотних відходів) теж збільшились на 8029 тис. грн. або на
0,05\% при тому що, амортизація зменшилась на 1033 тис. грн., або на 0,01\%, витрати на оплату праці теж зменшились на 1298 тис. грн., відрахування на соціальні заходи зменшилися на 424 тис. грн., або на 
0,02\%. Дані таблиці показують що аналіз впливу окремих факторів на зміну собівартості реалізованої продукції зросли в порівнянні з попереднім роком на 6151тис. грн.

Зауважимо, що будь-яке підприємство намагається мінімізувати витрати та шукає шляхи вирішення цього питання. Як правило, на діяльність підприємства впливають чимало груп факторів, а саме [10]:

- витратоутворюючі фактори (за теорією Дж. Ріле): функціональні та структурні;

- за сферою дії: фактори зовнішнього та внутрішнього середовища підприємства;

- за суб'єктами впливу: загальнодержавні, галузеві, внутрішнього виробничі;

- фактори, що впливають на витрати у загальному вигляді: виробничі та позавиробничі.

Грінченко А.В., досліджуючи класифікації факторів впливу на витрати, наголошує на те, що спостерігається дія синергетичного ефекту [10]. Так, ми згодні 3 тим, що кожний фактор має вплив та $є$ частинною системної дії на поліпшення ефективності підприємства та отримання позитивного фінансового результату.

Висновки та перспективи подальших досліджень. Проведені дослідження підтверджують важливість розуміння сутності категорії «доходи», «витрати», «собівартість» та «фінансовий результат», оскільки вони займають вагоме місце в організації та введені своєчасного обліку кожного підприємств. В результаті дослідження ми визначили, що «доходи»це $\epsilon$ збільшення активів в результаті ефективної роботи та конкурентоспроможності підприємства. А «витрати»- це зменшення ресурсів, призначені для виробництва та реалізації продукції на арені сучасного ринку. Сутність поняття «собівартості» полягає у підсумку всіх витрати пов'язані з виробництвом і реалізацією продукції. А перевищення доходів над витратами свідчить про позитивний фінансовий результат, тобто прибутку.

В результаті дослідження динаміки і структури витрат ПП Фірма «Гармаш», а також аналізу впливу окремих факторів на зміну собівартості реалізованої продукції визначено, що собівартість продукції має тенденцію до збільшення, а витрати на збут і адміністративні витрати - навпаки, зменшились. Таким чином, на досліджуваному підприємстві в звітному році прямі виробничі витрати є фактором, який має бути детально досліджуваний.

В умовах сьогодення однією зі складових успішної організації обліку і оцінки наявності та зміни фінансового результату є підвищений рівень застосування облікових даних для оцінювання, контролю та запобігання перевитрат. Слід відзначити, що для будь-якого підприємства своєчасно виявлення причин перевитрат і прийняття рішень, щодо виправлення, є одним із шляхів ефективної конкурентоздатності в сучасних умовах ведення бізнесу.

\section{Література}

1. Лагодієнко Н.В. Облік і контроль фінансових результатів на сільскогосподарських підприємствах / Н.В. Лагодієнко, В.М. Ковальчик // Бізнес-Навігатор. - 2014. - №1(33). - С.167-172.

2. Національне положення (стандарт) бухгалтерського обліку 1 «Загальні вимоги до фінансової звітності» : Наказ Міністерства фінансів України від 07.02.2013 р. № 73 : за станом на 17.02. 2017. [Електронний ресурс]. - Режим доступу: http://search.ligazakon.ua/__doc2.nsf/link1/RE22868.html

3. Податковий кодекс України від 02.12.2010 року № 2755-VI: за станом на 01.01.2018 p. [Електронний pecypc]. - Режим доступу: http://zakon3.rada.gov.ua/laws/show/2755-17

4. Положення (стандарт) бухгалтерського обліку 16 «Витрати» : Наказ Міністерства фінансів України від 31.12.1999 p. N 318: за станом на 27.06.2013. [Електронний ресурс]. - Режим доступу: http://search.ligazakon.ua/l_doc2.nsf/link1/REG4248.html

5. Бондаренко Н.М. Собівартість продукції: економічна сутність та іï види / Н.М. Бондаренко, А.К. Устименко // Науковий вісник Херсонського державного університету. - 2015. - Вип.11, Ч. 2. - С.51-54.

6. Сопко В.В. Бухгалтерський облік [Електронний ресурс] / В.В. Сопко. - Режим доступу: http://fingal.com.ua/content/view/780/35/1/3/]

7. Ткаченко Н. М. Бухгалтерський фінансовий облік, оподаткування і звітність : [підручник] / Н. М. Ткаченко. - [3-те вид. доп.і перероб.]. - К. : Алерта, 2008. - 926 с.

8. Бутинець Ф.Ф. Бухгалтерський фінансовий облік: [підруч. для студ. спец. «Облік і аудит» вищих навчальних закладів] / Ф.Ф. Бутинець. - [7-ме вид., доп. і перероб.]. - Житомир: Рута, 2006. - С. 832.

9. Чебанова Н.В. Фінансовий облік: [підручник] / Чебанова Н.В., Єфіменко Т.І. - К.: ВЦ «Академія», 2007. $-704 c$.

10. Грінченко А. В. Класифікація факторів впливу на витрати підприємства [Електронний ресурс] / А. В. Грінченко // Теоретичні та прикладні питання економіки. - 2012. - Вип. 27(1). - С. 392-398. - Режим доступу: http://nbuv.gov.ua/UJRN/Tppe_2012_27(1) 52 


\section{Маркова Т.Д. \\ кандидат экономических наук, старший преподаватель E-mail: markova.tetiana17@gmail.com}

\author{
Тройнина В.В. \\ магистрант \\ E-mail: verba1409@yahoo.com
}

Чорная С.В.

магистрант

кафедра учета и аудита

Одесская национальная академия пищевых технологий ул. Канатная, 112, г. Одесса, Украина, 65039

E-mail:sv.chornaya@yandex.ru

\section{ОЦЕНКА ВЛИЯНИЯ РАСХОДОВ И ДОХОДОВ НА ФИНАНСОВЫЕ РЕЗУЛЬТАТЫ НА ПРИМЕРЕ ЧП ФИРМА «ГАРМАШ»}

В статье рассматривается сущность понятия «расходы», «себестоимость», «доходы», «финансовый результат», теоретические и практические аспекты организации учета затрат и доходов деятельности и фринансовых результатов на предприятии. Проведенные исследования подтверждают важность понимания сущности этих категорий, поскольку они занимают важное место в организации и введение своевременного учета каждого предприятия. В результате исследования мы определили, что «доходы» - это увеличение активов в результате эффективной работы и конкурентоспособности предприятия. А «расходы» - это уменьшение ресурсов, предназначенные для производства и реализации продукции на арене современного рынка.

Учитывая сложное финансовое состояние во всех отраслях экономики и значительное количество убыточных предприятий и организаций, исследована динамика и структура затрат на примере ЧП Фирмы «Гармаш».

Учитывая значительную часть операционных расходов, проведено их анализ по экономическим затратам, анализ влияния отдельных фракторов на изменение себестоимости реализованной продукции, анализ затрат на 1 гривну продукции. Определены основные группы фракторов, влияющих на фринансовые результаты предприятия.

В результате, определено, что себестоимость продукции имеет тенденцию к увеличению, а расходы на сбыт и административные расходы - наоборот, уменьшились. Таким образом, на исследуемом предприятии в отчетном году прямые производственные затраты являются фрактором, который должен быть подробно рассмотрений для принятия управленческих решений. Определено, что каждый фактор влияет и является частной системного действия на улучшение эффективности предприятия и получения положительного финансового результата.

Предлагается в условиях современной адаптации для успешной организации учета и оценки наличия и изменения финансового результата повысить уровень применения учетных данных для оценки, контроля и предотвращения перерасхода. Выявлено, что одним из путей эффективной конкурентоспособности в современных условиях ведения бизнеса является своевременное выявление причин перерасхода и принятия решений по их устранению.

Ключевые слова: финансовые результаты, затраты на 1 грн, расходы деятельности, себестоимость, доходы деятельности, прибыль, убыток.
Markova T.
Ph.D., Assistant
E-mail: markova.tetiana17@gmail.com
Troinina V.
Undergraduate
E-mail: verba1409@yahoo.com

Chorna S.

Undergraduate

Department of Accounting and Auditing

Odessa National Academy of Food Technologies

Kanatna str., 112, Odessa, Ukraine, 65039

E-mail: sv.chornaya@yandex.ru

\section{ASSESSMENT OF THE IMPACT OF EXPENSES AND INCOME ON FINANCIAL RESULTS FROM THE EXAMPLE OF "GARMASH" PP FIRM}

In the article the essence of the concept of "outlay", "cost", " revenue ", " financial result " theoretical and practical aspects of cost accounting and revenue activities and financial results of the company have 
been considered. The conducted studies confirm the importance of understanding the essence of these categories, as they occupy an important place in the organization and the introduction of timely accounting of each enterprise. As a result of the research, we determined that "income" is an increase in assets as a result of effective work and competitiveness of the enterprise. And "expenses" are the reduction of resources intended for the production and sale of products in the arena of the modern market.

Taking into account the complicated financial situation in all sectors of the economy and a significant number of unprofitable enterprises and organizations, the dynamics and cost structure have been studied using the example of the private enterprise "Garmash".

Considering a significant part of operating expenses, their analysis has been carried out by economic costs; the analysis of the influence of certain factors on the change in the cost of sales and the analysis of costs by UAH 1 products have also been carried out. The main groups of factors influencing the financial results of the enterprise are determined.

As a result, it has been determined that the cost of production tends to increase, and the cost of sales and administrative costs, on the contrary, has decreased. Thus, at the enterprise under study in the reporting year, direct production costs are a factor that must be considered in detail for making managerial decisions. It has been determined that each factor influences and is a particular systemic action for improving the efficiency of the enterprise and obtaining a positive financial result.

It has been proposed to increase the level of application of accounting data for assessment, control and prevention of overspending in the context of modern adaptation for the successful organization of accounting and assessment of the availability and changes in the financial result. It has been revealed that one of the ways of effective competitiveness in the current business environment is the timely identification of the causes of overspending and decision-making on their elimination. it, loss.

Keywords: financial results, expenses for $1 \mathrm{UAH}$, expenses of activity, cost, operating income, prof-

\section{References}

1. Lahodiienko, N. V., \& Kovalchyk, V. M. (2014). Oblik i kontrol finansovykh rezultativ na silskohospodarskykh pidpryiemstvakh. Biznes-Navihator, (1 (33)), 167-172.

2. Natsionalne polozhennia (standart) bukhhalterskoho obliku 1 «Zahalni vymohy do finansovoi zvitnosti»: Nakaz Ministerstva finansiv Ukrainy vid 07.02.2013 r. № 73 : Za stanom na 17.02. 2017. (2017). Retrieved from http://search.ligazakon.ua/l_doc2.nsf/link1/RE22868.html

3. Podatkovyi kodeks Ukrainy vid 02.12.2010 roku № 2755-VI: Za stanom na 01.01.2018 r. (2018). Retrieved from http://zakon3.rada.gov.ua/laws/show/2755-17

4. Polozhennia (standart) bukhhalterskoho obliku16 «Vytraty»: Nakaz Ministerstva finansiv Ukrainy vid 31.12.1999 r. $\mathrm{N}$ 318: $\mathrm{Za}$ stanom na 27.06.2013. (2013). Retrieved from http://search.ligazakon.ua/__doc2.nsf/link1/REG4248.html

5. Bondarenko, N. M., \& Ustymenko, A. K. (2015). Sobivartist produktsii: Ekonomichna sutnist ta yii vydy. Naukovyi Visnyk Khersonskoho Derzhavnoho Universytetu, (11), 2nd ser., 51-54.

6. Sopko, V. V. Bukhhalterskyi oblik. Retrieved from http://fingal.com.ua/content/view/780/35/1/3/]

7. Tkachenko, N. M. (2008). Bukhhalterskyi finansovyi oblik, opodatkuvannia i zvitnist (3-te vyd. dop.i pererob. ed.). K.: Alerta.

8. Butynets, F. F. (2006). Bukhhalterskyi finansovyi oblik (7-me vyd., dop. i pererob. ed.). Zhytomyr: Ruta.

9. Chebanova, N. V., \& Yefimenko, T. I. (2007). Finansovyi oblik. K.: VTs «Akademiia».

10. Hrinchenko, A. V. (2012). Klasyfikatsiia faktoriv vplyvu na vytraty pidpryiemstva. Teoretychni Ta Prykladni Pytannia Ekonomiky, (27(1)), 392-398. Retrieved from http://nbuv.gov.ua/UJRN/Tppe_2012_27(1)_52 